\title{
Epidemic Preparedness Survey in Learning Respiratory System for Junior High School Students for Students' Preparedness in Facing Outbreaks in the Respiratory System
}

\author{
Dewi Kurnia Herowati,Arsy Husnanda, Nedia Erlini, Jumadi \\ Science Education Study Program, Postgraduate Program, Yogyakarta State University
}

\begin{abstract}
This study aims to determine the epidemic preparedness of junior high school students who have studied the respiratory system against the Covid-19 outbreak. Classification of diseases including pandemics, endemics or epidemics based on the area affected in a certain time. The increasing epidemic of Covid-19 has an impact on health, social and economy, especially in developing countries so that epidemic preparedness needs to be carried out for timely detection of epidemics followed by prompt and appropriate responses. This type of research is a qualitative descriptive study, with the research design used is survey research. The subject of this study consisted of 554 junior high school students in several areas including West Java, Central Java, Special Region of Yogyakarta, East Java, and Batam. The students have learned the respiratory system. Data collection was carried out in May 2020. The data collection method used was an online questionnaire through Google Form about epidemic preparedness especially Covid-19 which is a respiratory system disease. The results of the analysis showed that endemic preparedness in 8th and 9th grade junior high school students in several schools in Indonesia, showed an index of 73.97. That number is between 65 to 79 so that it can be categorized as advanced in endemic preparedness in the face of the current Covid-19 pandemic outbreak. The conclusion of this study is that the epidemic preparedness of junior high school students on the Covid-19 outbreak falls into the "Advanced" category.

Keywords: Epidemic preparedness, Respiratory System, Respiratory System Outbreak
\end{abstract}

\section{INTRODUCTION}

Science is a science that seeks answers to the questions of what, why, and how natural phenomena, so that science is able to provide sufficient space for the development of scientific attitudes, practice the process of solving problems, and their application in real life. Science is a human effort in understanding the universe through proper observation of the target, and using procedures, and explained with reasoning so as to get a conclusion. Science learning is learning that gives an understanding of the statement of relevance and shapes the perceptions of secondary school students about the use and role of science in everyday life (Schmidt, 2018). Science learning emphasizes the activeness of students to understand a phenomenon from all sides directly so that it has an impact on the meaningfulness of the material being studied. According to Trianto (2012: 136), science is a collection of systematic theories, its application is generally limited to natural phenomena, born and developed through scientific methods such as observation and 
experimentation and requires scientific attitudes such as curiosity, openness, honesty, and so. One of the basic competencies of junior high school students that refers to everyday life is the material of the respiratory system, namely KD 3.9 Analyzing the respiratory system in humans and understanding disorders of the respiratory system, as well as efforts to maintain the health of the respiratory system.

Breathing or respiration is a process ranging from oxygen uptake, expenditure of carbohydrates to the use of energy in the body. Humans inhale breathe oxygen in free air and dump carbon dioxide into environment. Parts of the respiratory system are the nose, pharynx, larynx, trachea, bronchus, bronchioles, and alveoli. The human respiratory system consisting of several organs can be disrupted. This disorder is usually in the form of abnormalities or diseases. Diseases or disorders that attack the respiratory system can cause interrupted respiratory processes. An endemic plague that attacks the respiratory tract is Covid-19. Children and adolescents must understand basic and age-appropriate information about corona virus disease, including symptoms, complications, how it is transmitted and how to prevent transmission (UNICEF, 2020).

Corona virus Disease 2019 or Covid-19 is a lung inflammation disease caused by Severe Acute Respiratory Syndrome Coronavirus 2 (SARS-CoV-2). Clinical symptoms that appear vary, such as symptoms of the common cold (cough, runny nose, sore throat, muscle aches, headache) to severe complications (pneumonia or sepsis). Classification of diseases including pandemics, endemics or epidemics based on the area affected in a certain time. If it is very wide and simultaneous spread, then it can be called a pandemic. Corona has spread to more than 169 countries of the world with mortality rates according to John Hopkins University and Medicine until March 24, 2020 as many as 17,241 people. In Indonesia there are 686 cases with 55 people dead. Corona or Covid-19 virus is still a family with SARS and MERS. However, Corona spreads the fastest among humans. Reuters data on February 1, 2020 stated, the virus that originated in Wuhan, China struck 1000 people in the first 48 days.

The increasing epidemic of Covid-19 has an impact on health, social and economy, especially in developing countries so that epidemic preparedness needs to be carried out for timely detection of epidemics followed by prompt and appropriate responses. Preparedness (preparedness) is a series of activities carried out to anticipate the Covid-19 outbreak through organization and through appropriate and efficient steps (Rijanta, 2014: 38). Aini Mat Said (2011) states that Preparedness is defined as actions taken in advance of an emergency to develop 
operational capabilities and to facilitate an effective response in the event that an emergency occurs. Preparedness is important and essential because effective preparedness helps save lives, reduce injuries, limit property losses and minimize all sorts of disruptions that disasters cause.

The community must always be vigilant because outbreaks of illness are unexpected, what can be done is to try to minimize the spread that will occur with these events. LIPI and ISDR (2006) in Dodon (2013) suggested several indicators of preparedness including public knowledge of natural events and the Covid-19 outbreak, community knowledge of physical environmental vulnerability, public attitudes and concerns about the risk of the Covid-19 outbreak, emergency planning for evacuation plans, emergency planning for first aid, rescue, safety and security, the Covid-19 outbreak warning system, and resource mobilization (Umu Siti Solikhah, 2016: 3).

One of the following immunization strategies can be considered: 1) immunizing all children in the target age group in neighboring areas where outbreaks are likely to spread; 2) immunize all children in the target age group in the affected area. The first approach is the one most likely to affect the spread of transmission in a cost effective manner, because children around the outbreak tend to get infected quickly. The most geographically vulnerable populations are identified by reviewing the epidemiology of the current outbreak (age distribution, settings, population subgroups, etc.) The next step is to find similar groups in the surrounding area, where no cases are identified. These groups are then targeted for additional immunization activities. Vaccinating children in the area of the outbreak may have little effect because most of the vulnerable people around this case may have been exposed to the virus at the time the response began (WHO, 1999).

Pathogens are transmitted through direct contact between vulnerable and infective populations. Assume further that the density of awareness programs increases at a rate proportional to the infective population. The complex dynamic behavior of the proposed model is discussed and appropriate strategies are sorted to control and eradicate the disease. Epidemic outbreaks through physical contact networks can trigger the spread of information awareness through other different channels, such as online social networks, mass media; on the other hand, an individual can not only be informed by other conscious neighbors but can also become self-awareness after some friends in the contact network are infected (Zuo, 2014; Samantha, 2013; Kar, 2019). This study aims to determine the epidemic preparedness of junior high school students who have studied the respiratory system against the Covid-19 outbreak. 


\section{METHODS}

This type of research is a qualitative descriptive study. The research design used in this study is survey research. Descriptive survey method used in this study is also known as the normative survey method because it is based on an assumption that certain phenomena usually follow general patterns or certain patterns. This is certainly closely related to the purpose of the research, which is to know the epidemic preparedness of junior high school students who have studied the respiratory system for the Covid-19 outbreak. The research subjects consisted of 550 junior high school students in several areas, including West Java, Central Java, Special Region of Yogyakarta, East Java, and Batam. These students have learned the respiratory system. Data was collected in May 2020 when the Covid-19 pandemic took place in Indonesia. The data collection method used was an online questionnaire via Google Form about epidemic preparedness especially Covid-19 which is a respiratory system disease. The analysis questionnaire was a checklist. Based on data collection techniques, the instrument used in this study was a questionnaire sheet. The checklist questionnaire sheet contains a number of statements compiled with 2 alternative answers Yes and No.

Table 1. Indicators of Endemic Preparedness for the Covid-19

\begin{tabular}{|c|c|c|c|}
\hline No. & Parameters & Variable & Indicator \\
\hline \multirow[t]{3}{*}{1} & \multirow{3}{*}{$\begin{array}{l}\text { Knowledge } \\
\text { and attitude }\end{array}$} & \multirow[t]{2}{*}{ Policy } & An education policy towards the Covid-19 outbreak \\
\hline & & & $\begin{array}{l}\text { There is a guide to community knowledge of the Covid- } \\
19 \text { outbreak }\end{array}$ \\
\hline & & Attitude & $\begin{array}{l}\text { Public attitudes and concerns about the risk of the Covid- } \\
19 \text { outbreak }\end{array}$ \\
\hline \multirow[t]{2}{*}{2} & \multirow{2}{*}{$\begin{array}{l}\text { Emergency } \\
\text { response } \\
\text { plan }\end{array}$} & $\begin{array}{l}\text { Important facilities } \\
\text { (hospital, police) }\end{array}$ & $\begin{array}{l}\text { Availability of addresses and telephone numbers of } \\
\text { important facilities }\end{array}$ \\
\hline & & Evacuation Plan & Availability of site plans for Covid-19 outbreak patients. \\
\hline \multirow[t]{2}{*}{3} & \multirow{2}{*}{$\begin{array}{l}\text { Endemic } \\
\text { Warning } \\
\text { System }\end{array}$} & \multirow{2}{*}{$\begin{array}{lr}\text { Dissemination } & \text { of } \\
\text { warnings } & \text { and } \\
\text { mechanisms }\end{array}$} & $\begin{array}{l}\text { Covid-19 plague warning information distribution } \\
\text { procedures are available }\end{array}$ \\
\hline & & & Access to information sources for the Covid-19 outbreak \\
\hline \multirow[t]{3}{*}{4} & \multirow[t]{3}{*}{$\begin{array}{l}\text { Resource } \\
\text { Mobilization }\end{array}$} & $\begin{array}{l}\text { Institutional } \\
\text { arrangement }\end{array}$ & $\begin{array}{l}\text { The availability of a team tasked with a Covid-19 } \\
\text { epidemic emergency }\end{array}$ \\
\hline & & $\begin{array}{l}\text { Communication and } \\
\text { coordination between } \\
\text { relevant stakeholders }\end{array}$ & School involvement in Covid-19 outbreak preparedness \\
\hline & & $\begin{array}{l}\text { Monitoring and } \\
\text { evaluation }\end{array}$ & $\begin{array}{l}\text { Plans are available to integrate Covid-19 outbreak } \\
\text { preparedness material into relevant subject curricula, } \\
\text { local content or extracurricular activities }\end{array}$ \\
\hline
\end{tabular}

Adaptation Source: RI Ministry of Health, 2020: 71; Umu Siti Solikhah, 2016: 3 
Data on epidemic preparedness of dialysis students using a questionnaire. The qualitative data analysis technique used in this study is descriptive statistical analysis (Asrizal, 2017: 3). Shaped paragraphs that are equipped with tables and graphs. Component measurements were carried out descriptively quantitative using the average score percentage of each aspect, the formula used as follows.

$$
\text { Percentage }(\%)=\frac{\text { total score of each aspect }}{\text { total of students }} \times 100 \%
$$

(Arikunto, 2013)

Techniques used in analyzing endemic preparedness data of students against disasters use primary data derived from questionnaires, then processed into preparedness indexes. By using the formula:

$$
\text { Index }=\frac{\text { Total Parameter Real Score }}{\text { Maximum Parameter Score }} x 100
$$

Source: LIPI-UNESCO/ISDR, 2006

The total real score parameter is obtained by adding up the real sum of all questions in the parameter concerned. The maximum score is obtained from the number of questions in the indexed parameters (each question is worth one). The range of disaster preparedness index value categories can be seen in Table.2.

Table 2. Disaster Preparedness Index Value

\begin{tabular}{|l|c|c|}
\hline No & Index value $(\%)$ & Category \\
\hline 1 & $80-100$ & Exemplary \\
\hline 2 & $65-79$ & Advanced \\
\hline 3 & $55-64$ & Proficient \\
\hline 4 & $40-54$ & Basic \\
\hline 5 & $\leq 39$ & Developmental \\
\hline
\end{tabular}

Source: LIPI-UNESCO / ISDR (2006)

\section{RESULTS AND DISCUSSION}

Corona virus Disease 2019 or Covid-19 is a respiratory system disease of lung inflammation caused by Severe Acute Respiratory Syndrome Coronavirus 2 (SARS-CoV-2). According to the World Health Organization (WHO), Covid-19 is transmitted through people who have been infected with the corona virus. The disease can spread through small droplets from the nose or mouth when someone who is infected with gasoline or coughs. The drops then reach an object or surface which is then touched by a healthy person, then the healthy person touches their 
eyes, nose or mouth. Corona virus can also spread when small droplets are inhaled by a person when in close proximity to an infected corona.

Covid-19 is called a pandemic disease because almost all countries are exposed to this virus. Based on information on detikNews with the last update on Saturday 30 May 2020 there were 216 countries exposed to Covid-19. Covid-19 positive confirmed number of 5,819,962 people, and died as many as 362,786 people. Whereas in Indonesia the positive case for Covid-19 was 25,773 people, with 7,015 patients recovered, and 1,573 died. This is the background of researchers to make a survey of endemic preparedness in junior high school students in some areas. The endemic preparedness survey questionnaire survey for junior high school students can be seen in Figure 1.

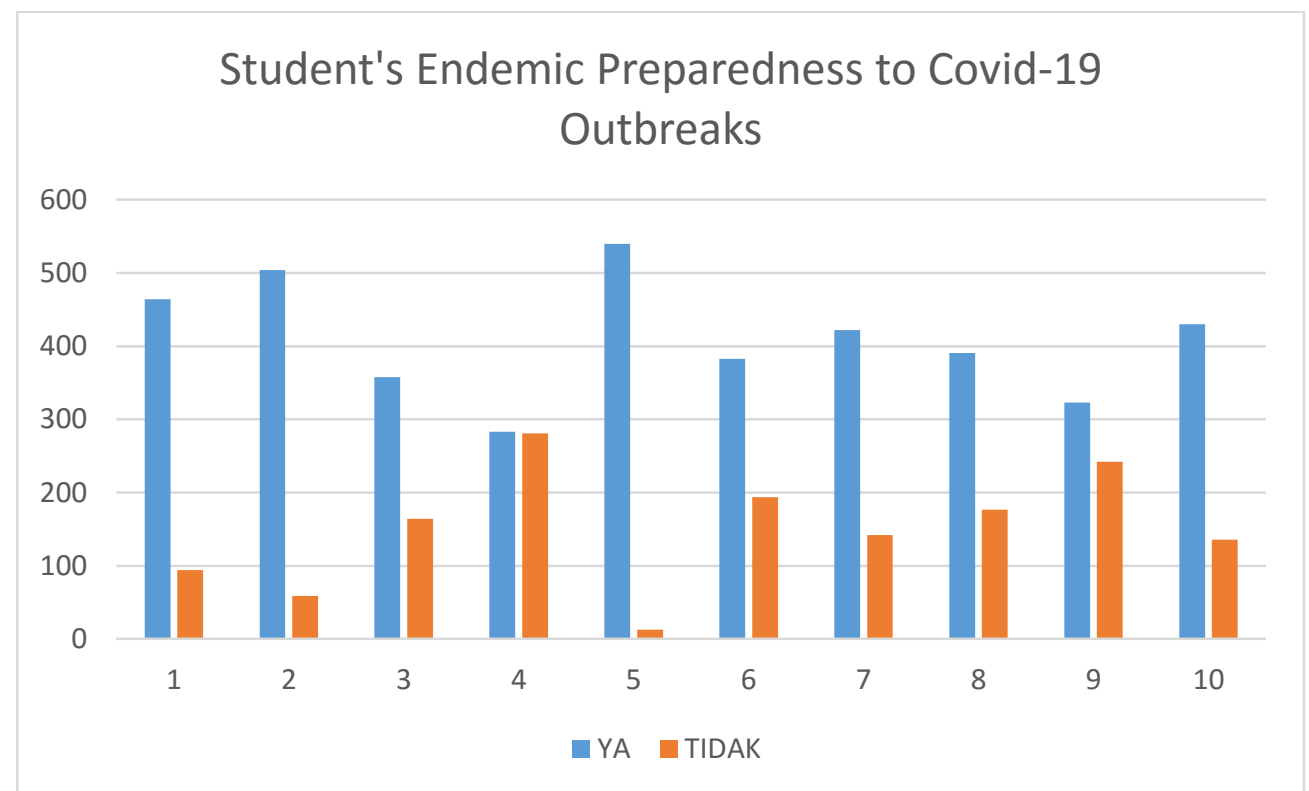

Figure 1. Diagram of Epidemic Preparedness Survey in Junior High School Students

After getting data about the epidemic preparedness survey questionnaire on junior high school students then analyzed using the preparedness index formula. Overall, students in grade VIII and class IX in several regions have an endemic preparedness index of 73.97. That number is between 65 to 79 so that it can be categorized as ADVANCED in endemic preparedness in the face of the current Covid-19 pandemic outbreak. In detail, the first parameter index is knowledge and attitudes reaching 80.36, the second parameter about emergency response plans has an index number 49.87, the third parameter is the disaster warning system has an index number of 48.78 , and the last parameter that is resource mobilization reaches an index number of 69.33 . There are 
two indicators that are not ready in the face of the Covid-19 pandemic outbreak, namely the disaster warning system and resource mobilization.

Emergency response plan parameters include indicators of availability and telephone numbers of important facilities and planned locations for patients with the Covid-19 outbreak. While this disaster warning system has indicators of the availability of procedures for information distribution in the Covid-19 outbreak warning and access to information sources for the Covid-19 outbreak. While the parameters. This needs to be followed up by relevant parties to include addresses and telephone numbers of important facilities, provide planned locations for patients with the Covid-19 outbreak, disseminate information distribution procedures for the Covid-19 outbreak warning, and facilitate access to information sources for the Covid-19 outbreak so that people in Indonesia are better prepared for endemic preparedness in the outbreak of Covid-19 so as to cut the spread of corona in the human respiratory system.

\section{CONCLUSIONS AND RECOMMENDATIONS}

Based on the results of a survey on endemic preparedness in 8th and 9th grade junior high school students in several schools in Indonesia, showed that the endemic preparedness index (epidemic preparedness) was 73.97. that number is between 65 to 79 so that it can be categorized as ADVANCED in endemic preparedness in the face of the current epidemic of the Covid-19 pandemic. This research is in the form of survey data using a questionnaire distributed via Google

forms. Suggestions for further research are to be able to choose research subjects that are evenly distributed throughout Indonesia so that they can be concluded globally.

\section{REFERENCES}

Arikunto, S. 2012. Dasar-dasar Evaluasi Pendidikan. Jakarta :BumiAksara.

Bender, L. (2020). GUIDANCE FOR COVID-19 PREVENTION AND CONTROL Contact (Education, Issue March). UNICEF. Simulation, 44, 193-203. https://doi.org/10.1016/j.cnsns.2016.08.007

Crapo JD, Harmsen AG, Sherman MP, et al. (2000). Pulmonary immunobiology and inflammation in pulmonary diseases. Am J Respir Crit Care Med:162:1983-6

Dinwiddie R, Sharief N, Crawford O. (2002). Idiopathic interstitial pneumonitis in children: a national survey in the United Kingdom and Ireland. Pediatr Pulmono;34:23-9 
Kar, T. K., Nandi, S. K., Jana, S., \& Mandal, M. (2019). Stability and bifurcation analysis of an epidemic model with the effect of media. Chaos, Solitons and Fractals, 120, 188-199. https://doi.org/10.1016/j.chaos.2019.01.025

Mittman C, Edelman NH, Norris AH, et al.(1965). Relationship between chest wall and pulmonary compliance with age. J Appl Physiol. ;20:1211-16

Schmidt, J. A., Kafkas, S. S., Maier, K. S., Shumow, L., \& Kackar-Cam, H. Z. (2019). Why are we learning this? Using mixed methods to understand teachers' relevance statements and how they shape middle school students' perceptions of science utility. Contemporary Educational Psychology, 57(xxxx), 9-31. https://doi.org/10.1016/j.cedpsych.2018.08.005

Tim Detikcom. 2020. Berikut Sebaran Kasus Positif Corona 30 Mei, Terbanyak di 5 Provinsi Ini. DetikNews. Retrieved from https://news.detik.com/berita/d-5034698/berikut-sebaran-kasuspositif-corona-30-mei-terbanyak-di-5-provinsi-ini

World Health Organization. (1999). Guidelines for Epidemic Preparedness and Response to Measles Outbreaks. May. http://www.who.int/emc

Zuo, L., \& Liu, M. (2014). Effect of awareness programs on the epidemic outbreaks with time delay. Abstract and Applied Analysis, 2014. https://doi.org/10.1155/2014/940841 